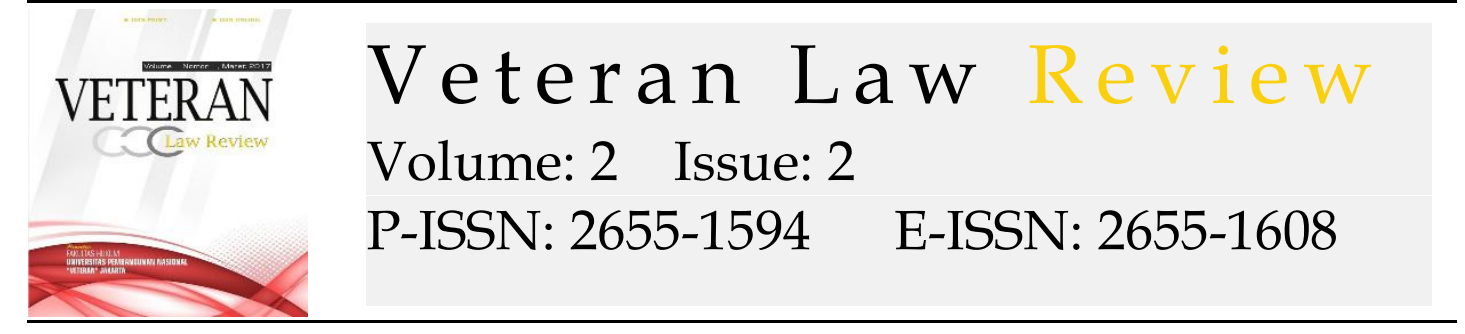

\title{
The Constitutional Design Of Application Of Overseas Citizenship of India (Oci) In The Indonesia Constitutional Law System
}

\author{
Ahmad Gelora Mahardika \\ Department of Constitutional Law, State Islamic Institute in Tulungagung, \\ Email : geloradika@gmail.com
}

\begin{tabular}{|c|c|}
\hline ARTICLE INFO & ABSTRACT \\
\hline $\begin{array}{l}\text { Keywords: } \\
\text { Diaspora; Citizenship; } \\
\text { Constitution Law. } \\
\text { How to cite: } \\
\text { Gelora Mahardika, } \\
\text { Ahmad (2019). The } \\
\text { Constitutional Design of } \\
\text { Application of Overseas } \\
\text { Citizenship Of India } \\
\text { (OCI) In The Indonesia } \\
\text { Constitutional Law } \\
\text { System. 2(2). hlm. 42-56 }\end{array}$ & $\begin{array}{l}\text { The idea of implementing a dual citizenship system in } \\
\text { Indonesia which was initiated by the Indonesian Diaspora was } \\
\text { directed towards imitating the Overseas Citizenship Of India } \\
\text { (OCI) concept in India. The concept is considered a middle } \\
\text { way between the demands of the Indian Diaspora and the } \\
\text { reluctance of the Indian Government to amend the constitution } \\
\text { regarding the principle of single citizenship. Indonesia also } \\
\text { currently applies a single citizenship principle even though it } \\
\text { is not regulated in the constitution. The idea of an } \\
\text { Indonesian diaspora to emulate the OCI concept in India looks } \\
\text { very rational, except that the problem is the extent to which the } \\
\text { concept is applicable in the Indonesian constitutional system. } \\
\text { What rules must be changed and which provisions must } \\
\text { adjust. Implications of the application of OCI can be the same } \\
\text { as dual citizenship, because the theory used is a residual } \\
\text { theory where, apart from the prescribed restrictions, OCI card } \\
\text { holders must be considered equal to Indonesian citizens. This } \\
\text { concept has the potential to create legal complexity if there is a } \\
\text { legal difference between Indonesia and other countries. } \\
\text { Copyright @2019 VELREV. All rights reserved. }\end{array}$ \\
\hline
\end{tabular}

\section{Introduction}

Law Number 12 of 2006 on Indonesian Citizenship as an amendment to Law Number 62 of 1958 is one of the important revolutions in the history of Indonesian constitutional law, specifically related to the law of citizenship. Law Number 12 of 2006 has 4 principles which function to protect citizenship status of Indonesian citizens, namely the principle of ius soli, the principle of ius sanguinis, the principle of single citizenship, and the principle of limited dual citizenship. ${ }^{1}$ The four principles are protected by two important principles, namely the principle of national interest and the principle of maximum protection. The principle of maximum protection is the principle

\footnotetext{
${ }^{1}$ Rokilah (2017), Implikasi Kewarganegaraan Ganda Bagi Warga Negara Indonesia, Ajudikasi, (Vol 1 No 2 Desember, p. 53-62)
} 
created by legislators to ensure that no Indonesian citizen loses citizenship status (stateless). ${ }^{2}$

On the progressive aspect, Law Number 12 of 2006 on Indonesian Citizenship has broken the establishment of the national legal system. This is because the existence of the previously Law No. 62 of 1958 on Indonesia Citizenship in its implementation often had the possibilities to eliminate citizenship status of Indonesian citizens who are overseas or descendants of Indonesian citizenship. However, apart from its breakthrough in national law, the application of Law No. 12 of 2006 on Indonesian Citizenship is still questioned by the Indonesian diaspora group who feel that the limited dual Citizenship Principle for 18-year-old mix-marriage children is proof of the Government's lack of strict dual citizenship principles. The Indonesian Diaspora Group proposes to the government to implement a not limited dual citizenship system to replace a single citizenship system that is considered detrimental to Indonesian diaspora groups. ${ }^{3}$ The concept that is considered ideal by the Indonesian diaspora is like what explicated in India, where in India the concept known as the Overseas Citizenship of India (OCI), a form of privilege granted by the state to citizens of Indian descent who have become foreign nationals. ${ }^{4}$ However, what needs to be noted is that the application of OCI does not change the status of India as a country that adheres to single citizenship principles as demanded by the Indonesian diaspora who want the application of unlimited dual citizenship principles. Conceptually, the application of the OCI scheme is considered the most rational concept compared to change the single citizenship system into dual citizenship. Because changing in the citizenship system will revise interpretations related to the definition of Indonesian citizens (WNI) in all legal aspects in Indonesia.

But implementing the OCI concept as in India is not an easy matter. The application of the OCI scheme will potentially convert a number of legal aspects in Indonesia. Looking at its history, the application of the OCI in 2005 was a third way given by the Government of India to the Indian Diaspora which demanded the adoption of a dual citizenship system. ${ }^{5}$ This is because the Indian constitution explicitly rejects the adoption of a dual citizenship system, even though in the fact, India also has limited dual citizenship. This can be seen in Article 370 and Article 35A of the Indian Constitution which recognizes Indian people registered in the state of Jammu and Kashmir ( $\mathrm{J}$ \&

\footnotetext{
${ }^{2}$ Kurniawan, M. Beni (2018), Penggunaan Diskresi Dalam Pemberian Status Kewarganegaraan Indonesia Terhadap Archandra Thahar Ditinjau Dari Asas Pemerintahan Yang Baik, De Jure, (Vol. 18 No. 2, Juni 2018, p. 149 - 162)

${ }^{3}$ https://tirto.id/saat-diaspora-indonesia-menuntut-kewarganegaraan-ganda-crPo accesed in 18 April 2019

${ }^{4}$ Khadria, Binod, (2009), Adversary Analysis and the Quest for Global Development Optimizing the Dynamic Conflict of Interest in Transnational Migration, Social Analysis,(Volume 53, Issue 3 , Winter 2009, p. 106-122)

${ }^{5}$ Liu Lisong, (2012), Return Migration and Selective Citizenship A Study of Returning Chinese Professional Migrants from the United States, Journal of Asian American Studies; (Vol. 15, Iss. 1, p: $35-68,143)$.
} 
K) as citizens of India, even though these two regions are still in conflict with Pakistan and include areas in under the supervision of the United Nations. ${ }^{6}$

Constitutionally, the application of the OCI does not violate the constitution insofar as it does not change the concept of citizens' political rights. But what then becomes a big question is how the constitutional design of the application of OCI is in the Indonesian constitutional system? This is important because the application of OCI will automatically add to the constitutional rights that have only been owned by Indonesian citizens then become Indonesian citizens and Indonesian citizens who are already aliens.

\section{Method}

This research is included in empirical research with studies that view law as a reality that includes social reality, reality of culture and others (reviewing law in action). ${ }^{7}$

\section{Main Heading of the Analysis or Results}

Citizenship status is a pre supposed right in the constitutional system. Without citizenship status, one cannot afford to access a number of constitutional rights granted by the state. This is in line with what Brubaker said, "Citizenship has been described as an international filling system a mechanism for allocating persons to states" (Brubaker,1992:31). Therefore, citizenship is considered to be a combination between citizens, countries and nations. Combined with facts that are inclusive and exclusive in citizenship discourse. In the historical aspect, the concept of citizenship that was previously more synonymous with ethnicity, race and certain groups slowly in the present era began to shift to the concept of a nation state, it was in line with what Sejersen delivered, ${ }^{8}$

Conceptualization of citizenship are being questioned as a result of the increased focus on the role of the nation-state. The changed nature of the framework of citizenship has been labeled as either "post national" (Soysal,1994), diasporic (Lagueree, 1998), Flexible (Ong, 1999) or Transnasional (Baubock, 1995). The significance for the social scientist is that dual citizenship provides a window through which to view the discussions regarding the future of the nation-state. The external pressure on nationstates has created an increasing number of countries with more relative view of the borders of the state. Territories have maintained their importance in a security sense, but the importance of territories for identity formation is decreasing (Jacobson, 2001). This development has been described as follows: "while boundaries have been penetrated, borders retain their essential characteristic as constructs that define the nature of exclusion in inclusion" (Newman, 2001:151)

\footnotetext{
${ }^{6}$ K. Soni Sharad, (2000), The United Nations Commission On Human Rights (55th Session): A Report, Himalayan and Central Asian Studies, (Vol. 4 No. 2, p. 35)

${ }^{7}$ Ali, Ahcmad dan Heryani, Wiwie, (2012), Menjelajahi Kajian Empiris terhadap Hukum, Jakarta: Kencana Prenada Media Group.

${ }^{8}$ Ibid.,
} 
Based on this discourse, the concept of dual citizenship was come into the world. Namely citizenship produced by two statuses namely ethnicity and nationality. The shift of the concept of citizenship from tribal to national state is not always interpreted positively by experts. Dual citizenship based on two aspects, namely ethnicity and nation state, for Spiro actually proves the failure that occurred in building the basic concept of nationalism, "Dual citizenship has been described as a result of a "failure to develop a universal rule of nationality" (Spiro, 1997:1417)

This failure has implicate for the demands of a group of parties for the enactment of a dual citizenship system in order to accommodate the adore of the homeland and the nation simultaneously. However, on the other hand, the idea often contradicts the basic conception of a country that adheres to the principle of single citizenship. An example is Indonesia; Indonesia's Diaspora Desire that Indonesia implements a dual citizenship system in conflict with positive laws in Indonesia that prohibit the adoption of a dual citizenship system. Law Number 12 of 2006 on Indonesian Citizenship applies 4 (four) principles related to citizenship status, namely, ${ }^{9}$

1) The principle of ius sanguinis: is the principle that determines one's nationality based on descent, not based on the country of birth.

2) The principle of ius soli: is the principle that determines one's nationality based on the country of birth

3) Principle of single citizenship: is the principle that determines one nationality for each person. The principle of single citizenship is the principle of citizenship status where every citizen cannot be dual citizenship.

4) The principle of limited dual citizenship: is the principle that determines dual citizenship for children in accordance with the provisions stipulated in the law.

The four principles mentioned above for the Indonesian Diaspora are considered insufficient to represent the desires of the Indonesian diaspora so that Indonesia implements a system of unlimited dual citizenship as if in European countries or the United States. However, if you look at the proportions, a country that embraces single citizenship is not necessarily a backward or developing country, or vice versa, a country that implements a dual citizenship system is not necessarily a developed country.

Countries that allow dual citizenship: Australia, Barbados, Belgium, Bangladesh, Canada, Cyprus, Denmark, United States, United Kingdom, Switzerland, South Korea, South Africa (requires permission), Egypt, Greece, France, Finland, Germany (requires prior permissions), Iraq, Italy, Israel, Ireland, Poland, Hungary, Iceland, Kenya, Sweden, Slovenia, Syria, Serbia, Armenia, Thailand, Lebanon, Malta, Spain (only with certain Latin American countries), Tonga, Philippines, Sierra Leone, Sri Lanka (by retention), Pakistan (accepts only with 16 countries), Portugal, Turkey (requires permission). ${ }^{10}$

\footnotetext{
${ }^{9}$ Asshidiqie, Jimly, (2007), Pokok-Pokok Hukum Tata Negara Indonesia, Jakarta: PT Bhuana Ilmu Populer, p. 669

10 http://dlgimmigration.com/united-states-citizenship/countries-that-allow-dualcitizenship/ accessed in 12 April 2019
} 
Meanwhile countries that do not allow dual citizenship are also not less numerous than the above list, namely: Andorra, Austria, Azerbaijan, Burma, Bahrain, Botswana, Japan, China, Czech Republic, Fiji, India, Indonesia, Ecuador, Estonia, Iran, Papua New Guinea, Brunei, Japan, Peru, Kuwait, Kazakhstan, Chile, Kiribati, Korea, Kuwait, Latvia, Singapore, Slovakia, Ecuador, Lithuania, Solomon Islands, Fiji, Malaysia, Mauritius, Netherlands, United Arab Emirates (UAE), Romania, Mexico, Nepal, Venezuela, Norway, Zimbabwe, Mauritius, Myanmar, Nepal.

It can be seen from the list above that there are a number of developed countries that do not apply a dual citizenship system such as Japan, Norway, the Netherlands, or China. This is actually an indication that the implementation of the citizenship system has no correlation with the progress of a country. Cumulatively, the application of a single and double citizenship system has advantages and disadvantages. In terms of advantages: ${ }^{11}$

1. It offers individuals an extend level of privileges and benefits.

2. It permits an individual to carry two passports.

3. It allows for property ownership in both nations.

4. It creates opportunities.

5. It allows for governments to create new revenue streams.

6. It keeps families together.

While the disadvantages are as follows:

1. It creates multiple obligations.

2. It creates multiple tax obligations.

3. It can create security issues.

4. It is expensive.

5. It can threaten the political identity of a country.

6. It may not be permitted.

7. It may include specific passport obligations.

8. It can be a lengthy process.

9. It could violate a person's oath of allegiance.

10. It may change access as politics change within a country.

One of the problems that hinder the adoption of dual citizenship principles in Indonesia is security issues. As is known that each country has central issues that are confidential and cannot be conveyed to foreign citizens. Therefore, one of the requirements to become a civil servant, police / military, state official and other law enforcement elements is a citizen. Even according to Tanja Brøndsted, "There is no doubt that dual citizenship does not fit a neat absolute definition a state as a closed territory with a defined homogenous citizenry" in the sense that the concept of dual citizenship does indeed make the state open and vulnerable to infiltration of certain interests. ${ }^{12}$

\footnotetext{
${ }^{11}$ https:/ / vittana.org/16-big-pros-and-cons-of-dual-citizenship accessed in 7 April 2019

${ }^{12}$ Sejersen, Tanja Brøndsted, I Vow to Thee My Countries" - The Expansion of Dual Citizenship in the 21st Century The International Migration Review: IMR; Thousand Oaks, Vol. 42, Iss. 3, (Fall 2008): p. 523-549
} 
Therefore, the dual citizenship system is a complicated problem in the Indonesian constitutional system. According to Benjamin Muller (2004), "dual citizenship creates individuals with a dual status who are full members in several states. They are simultaneously citizens and foreigners. With the increasing incidence of dual citizenship, the concept of citizenship is questioned even further and the normative foreigner - citizen dichotomy becomes questionable". ${ }^{13}$ The concept of dual citizenship creates confusion between citizens and foreign citizens; the concept of citizenship becomes unclear.

Amid the debate over the concept of dual citizenship, the Indonesian diaspora group consistently requested that the Indonesian Government immediately implement a dual citizenship system. But until now the request has not been fulfilled by the Government of Indonesia. However, the promise of a number of state officials to implement a dual citizenship system, make it is very urgent to make constitutional design related to the application of dual citizenship needs to be studied immediately. The demand of the Indonesian diaspora is the application of a dual citizenship system as applied in India with its OCI policy.

\section{Overseas Citizenship of Indian}

Overseas Citizenship of India (OCI) is one of the breakthroughs of law made by the Government of India regarding the insistence of Indian diaspora groups to implement a dual citizenship system. The change in the citizenship system in India is very difficult because the norms related to it are listed in the Indian constitution. OCI holders are not Indian citizens based on Indian law, and the rights received by OCI holders do not cover certain rights, namely the right to vote, the right to occupy government positions regulated in the constitution Right to hold constitutional offices, and the right to buy agricultural properties. ${ }^{14}$

Referring to the provisions governing the implementation of the Overseas Citizenship of India, OCI holders have the following conveniences: ${ }^{15}$

1. Multiple-entry, multi-purpose lifelong visa to visit India;

2. Exemption from foreigner registration requirements for any length of stay in India; and

3. Parity with non-resident Indians in financial, economic and educational fields except in the acquisition of agricultural or plantation properties.

Overseas citizenship of India is not an Indian citizen from the point of view of the Indian constitution and will not get the special rights of Indian citizens namely: ${ }^{16}$

1. they do not have the right to vote,

${ }^{13}$ Ibid.,

14 https://web.archive.org/web/20170422124533/https://in.usembassy.gov/u-s-citizenservices/citizenship-services/dual-nationality/ accessed in 10 April 2019

${ }^{15} \mathrm{https}$ // ociservices.gov.in/ accessed in 10 April 2019

16 https://www.ndtv.com/indians-abroad/supreme-court-dismisses-plea-for-voting-rightsof-overseas-citizens-756654 accessed in 10 April 2019 
2. they do not have the right to hold the offices of President, Vice-President, Judge of Supreme Court and High Court, Member of Lok Sabha, Rajya Sabha, Legislative Assembly or Council,

3. Appointment to Public Services (Government Service).

Although basically not "dual citizenship" in the real sense, the benefits obtained by OCI card holders are very large. OCI holders have more job opportunities because foreign companies tend to employ OCI card holders compared to Indian Citizens or Foreign Citizens, because in quality they are equal to foreigners but in the procedure as Indian Citizens.

This card also provides a long-term visa (a lifelong visa) to the holder, and frees them from having the need for permits. OCI card holders are treated equally with Non-Residents of India in economic, financial and educational aspects and only have no political rights, the right to buy agricultural land or serve in government. ${ }^{17}$

Since the launch of Overseas Citizenship in 2006, the Indian government has announced some 'additional benefits' during its annual diaspora conference, the Pravasi Bharatiya Divas. In 2007, OCI card holders were given parity with Indian citizens abroad in the matter of inter-country adoption of Indian children, for domestic air fares and for admittance into national parks and wildlife sanctuaries. In 2009, the Ministry of Overseas Indian Affairs granted OCI card holders parity with NRIs for working as doctors, dentists, nurses, pharmacists, advocates, architects and chartered accountants. And the parity with NRIs was extended to entry fees for national monuments, historical sites and museums. Further in 2012, the privilege was added that Indian State governments should ensure that OCI registration booklets are treated as overseas citizens' identification and included a facilitated rule for providing proof of residence. ${ }^{18}$

They are also exempt from registration with the Foreigners Regional Registration Officer (FRRO) on their arrival in the country and can stay or live in India for as long as they wish. OCI cardholders can travel at very short notice and take up assignments in India, while others could get caught up in bureaucratic delays over their employment visa. Many companies are following an active policy of moving PIOs to India for business expansion. Indian missions overseas are witnessing a deluge in OCI applications, the number of OCI cards issued by diplomatic missions around the world have been steadily rising with several Indian diplomatic missions grappling with a huge backlog of applications ${ }^{19}$

Research on the effects of Overseas Citizenship of India shows three effects. (a) It enables overseas citizens by granting special privileges; (b) it affects expectations about privileges; and (c) it eases the transaction process and reducing costs and risks. Regarding the latter, a special status like OCI reduces the actual and expected cost of an operation through exemptions

\footnotetext{
17 Daniel Naujoks. (2013), Migration, Citizenship, and Development. Diasporic Membership Policies and Overseas Indians in the United States. New Delhi: Oxford University Press, p.8

${ }^{18} \mathrm{Ibid}, \mathrm{p} .9$

${ }^{19}$ https:/ / economictimes.indiatimes.com/oci-cardholders-are-hot-forindianassignments/articleshow/5231433.cms accessed in 15 April 2019
} 
from formal requirements and by serving as official proof of being entitled. ${ }^{20}$ In short, the OCI has a very vital influence to reduce the actual costs of an activity by eliminating formal requirements which have been bureaucratic.

Based on the above explanations, it can be concluded that there are several special rights that will be obtained by OCI card holders, namely:

1) The right to stay in India for a long time

2) The right to be equalized with Indian citizens, related to the obligation to register foreigners

3) Equality with Indian citizens in the fields of finance, economics and education

4) The right to adopt Indian children

5) Equality with Indian citizens related to access to tourist attractions

6) Right to get a job without a work permit

\section{The Constitutional Design of Application of Overseas Citizenship of India (OCI) In Indonesia}

The insistence of diaspora groups to apply the OCI card concept to the Indonesian diaspora is still trapped in dilemmatic problems. This is related to OCI's constitutionality in the Indonesian constitutional system. As written in the previous sub-chapter, there are several privileges obtained by OCI card holders. If the rights are converted into Indonesian law, the results are as follows :

1) The right to stay in Indonesia for a long time

2) The right to be equalized with Indonesian citizens, related to the obligation to register foreign nationals

3) Equality with Indonesian citizens in the fields of finance, economics and education

4) The right to adopt Indonesian children

5) Equality with Indonesian citizens related to access to tourist attractions

6) Right to get a job without a work permit

Looking at the rights mentioned above, there are several laws that must be adjusted if Indonesia really wants to replicate the OCI concept in the Indonesian constitutional system.

\section{The Right to Stay in Indonesia for a Long Time}

Regarding the right of foreign citizens to stay for a long time, there are several laws and regulations that prohibit foreigners from staying in Indonesia for a long time without certain permits, in Law No. 6 of 2011 concerning Immigration regulated in Article 34 that:

Visas consist of:
a. Diplomatic visa;
b. Official visa;
c. Visit visa; and
d. Limited residence visa.

${ }^{20}$ Daniel Naujoks, Op.Cit, p.11 
The provision shows that foreigners who can live in the territory of the Republic of Indonesia must have a visa, and each visa has a limit of stay within a certain time, except diplomatic visas. But on the other hand, there are a number of aliens who can enter the territory of Indonesia without a visa. This can be seen in Article 43:

1) In the particular case of Alien could be exempted from the requirement to hold a visa.

2) Foreigners are exempt from the requirement to hold a visa referred to in paragraph (1) is:

a. nationals of certain countries which are established under Presidential Decree with regard to the principle of reciprocity and the principle of utility;

b. Permit holders of foreign nationals who have entry permits Stay Back which is still valid;

c. captain, pilot captain, or crew on duty on conveyances;

d. Skippers, crew, or expatriate expert on board a ship or floating device that comes directly to the transport means to operate in the archipelago waters, territorial sea, continental shelf, and / or the Exclusive Economic Zone of Indonesia.

Later when OCI is implemented, OCI holders can enter the territory of Indonesia without a visa, so there are several things that need to be changed in Law No. 6 of 2011 concerning Immigration which regulates the residence permit of foreigners.

1) It must be included in the general provisions relating to Overseas Citizenship of Indonesia (OCI) cardholders who are distinguished from foreign nationals

2) In Article 34, one verse can be added to be added related to OCI which can enter Indonesian territory without using a Visa and is free to stay in Indonesia for a long time.

The right to be equalized with Indonesian citizens, related to the obligation to register foreign nationals

In relation to this right, some norms in the immigration law must also be adjusted, in Article 14:

(1) Every citizen of Indonesia cannot be denied entry to Indonesia Region.

(2) In case of doubt on the travel document of a citizen of Indonesia and / or citizenship status, concerned must provide other evidence of legitimate and convincing showing that the person concerned is a citizen of Indonesia.

(3) In order to complete the proof referred to in paragraph (2), is concerned can be placed in a house or room Immigration Detention Immigration Detention.

If OCI is implemented in the Indonesian constitutional system, then article 14 paragraph (1) can be changed to "Every Indonesian citizen and OCI card holder cannot be denied entry into Indonesian territory". This is to equalize the treatment between Indonesian citizens and OCI card holders regarding registration to enter Indonesian territory. 


\section{Equality with Indonesian citizens in the fields of finance, economics and education}

The concept of equality between Indonesian citizens and WNA OCI card holders related to this aspect is the most vital. OCI card holders have an equal position with Indonesian citizens related to financial, economic and educational rights with the exception of the right to buy agricultural land. Related to property ownership according to the Indian Foreign Ministry, "OCI card holders can purchase residential and commercial properties in India. But they are not permitted to purchase agricultural land, including farmland or any kind of plantation property". In the sense that if implemented in the national legal system in Indonesia, OCI card holders have the right to buy housing and all property in the territory of Indonesia, except agricultural land.

If you look at the norm, there are several laws and regulations that need to be amend and adjusted. In Law No. 5 of 1960 concerning Basic Regulations on Agrarian Principles, the Nationality Principle was introduced which can be interpreted as meaning that only Indonesian citizens have ownership rights to land. (Article 21 Paragraph (1) juncto. Article 26 Paragraph (2) of the law) states that the property rights cannot be owned by foreigners and the transfer of ownership rights to foreigners is prohibited by threats null and void. In this principle it is affirmed that foreigners cannot own land in Indonesia and only Indonesian citizens can own land in Indonesia. So the land is only provided for citizens of the countries concerned. ${ }^{21}$

The principle of nationalism is in Law 5 of 1960 article 1 paragraphs (1) (2) and (3). Article 1 paragraph (1) Law 5 of 1960, states that" The entire territory of Indonesia is a unified motherland of the whole of the Indonesian people who are united as the Indonesian Nation.". Meanwhile in the article 1 paragraph (2) Law on Agrarian Principle, states that "The entire earth, water and airspace, including the natural resources contained therein, in the territory of the Republic of Indonesia as the gifts of God Almighty are the earth, water and airspace of die Indonesian nation and constitute the wealth of the nation". This means that the earth, water, and space in the territory of the Republic of Indonesia are the rights of the Indonesian people, so they are not merely rights rather than their owners. Likewise, lands in the regions and islands are not solely the rights of the indigenous people of the region or island concerned. In Article 1 paragraph (3) of the Law 5 of 1960, it is stated that "The relationship between the Indonesian Nation and the earth, water as well as air space meant it in paragraph (2) of this Article is of an eternal nature.".

The application of OCI related to property ownership rights outside of agricultural land is a very complex matter, because it will change a number of provisions stipulated in the agrarian principal law on land ownership. However, the problem is that the provisions of this law are derived from

${ }^{21}$ Aggriani, Jum, ( 2012), Penerapan Asas Nasionalitas dalam Perundang-undangan Agraria Indonesia, Studi Kasus PP No. 40 Tahun 1996", Dinamika Hukum (Vol.12 No.1, p. 174) 
Article 33 of the 1945 Constitution which states that "Earth and water and the natural resources contained therein are controlled by the state and used for the greatest prosperity of the people" (Article 33 Paragraph 3). This article does not directly prohibit land ownership by foreigners, but this provision implicitly states that foreigners do not have the right to own land.

But related to the debate regarding the constitutionality of land ownership by foreigners, if the OCI concept is applied in the Indonesian constitutional system, then some norms in the Agrarian Law must also be adjusted. Article 21 states that,

"Only Indonesian citizens can have ownership rights"

Provisions related to this Article must be changed to,

"Only Indonesian citizens and OCI card holders can have ownership rights"

In addition to ownership rights issues, in terms of economics OCI card holders can also open special bank accounts in India such as Non Residents of India (NRI) and make investments, OCI cards also allow to obtain driver's licenses. Currently related to opening a bank account for foreigners, Financial Services Authority (OJK) has issued Circular Letter number S-246 / S.01 / 2015 dated September 15, 2015. The following are provisions for simplifying the requirements issued by OJK: ${ }^{22}$

1. Tourist Account with Limited Balance between 2,000 US dollars 50,000 US dollars: - Requirements for opening an account in the context of Customer Due Diligent (CDD) simply by showing an identity in the form of a passport. - First deposit of at least 2,000 US dollars and a maximum balance of 50,000 US dollars - The amount of the balance below 10,000 US dollars is subject to higher charges. Foreign exchange account with unlimited balance: - Account opening requirements in the context of CDD using passports and 1 (one) certain additional documents (for example: references from related banks in the foreign country of origin, local domicile certificate, wife's identity, copy of residence contract, or credit / debit card). - Balance of more than 50,000 US dollars.

2. Foreign exchange accounts with special balances - large amounts: Account opening requirements in the context of CDD use certain passports and additional documents (for example: references from related banks in the foreign country of origin, local domicile certificate, wife's identity, photocopy of residence contract, or credit / debit card). - Balance of more than US \$ 1 million: - Deposit interest tax is lower than tax in general, and is applied progressively (more balance, lower tax). - It is prioritized to open these accounts only by certain banks that meet the requirements of risk management and banking prudence.

The equality of treatment with Indonesian citizens related to ownership of a bank account means that OCI card holders do not need to use passports anymore by using an OCI card as a requirement to open a bank account. This

\footnotetext{
${ }^{22}$ https://money.kompas.com/read/2015/09/16/134501326/OJK.Terbitkan.Aturan.Penyed erhanaan.Buka.Rekening.Bank.untuk.WNA accessed in 12 April 2019
} 
also applies to driver license (SIM) ownership, OCI holders must be treated the same as Indonesian citizens.

Meanwhile in the field of education, OCI card holders are considered the same as Indonesian citizens. In that sense, the education costs incurred for OCI and Indonesian citizens must be the same. Article 32 paragraph (2) Regulation of the Minister of Education and Culture of the Republic of Indonesia Number 17 of 2017 concerning Acceptance of New Students in Kindergartens, Elementary Schools, Junior High Schools, High Schools, Vocational Schools, or other Similar Forms state that:

Provisions for foreign nationals to become students in the School must:

a. have Indonesian language skills for schools with an introduction to Indonesian;

b. fulfill the provisions stipulated in this Ministerial Regulation; and

c. Fulfill the provisions concerning foreign nationals in Indonesia in accordance with the provisions of the legislation.

Provisions related to this Legislation must be amended by giving an exception to the OCI card holder. A number of rules relating to scholarships that were previously only intended for Indonesian citizens must be changed to Indonesian citizens and foreigners who hold OCI cards.

\section{The right to adopt Indonesian children}

In the Government Regulation Number 54 of 2007 on the Implementation of Child Appointment, it is stated that as in the case of adoption by Indonesian citizens, the appointment of Indonesian citizens by foreigners is carried out through court decisions. However, there are additional requirements, namely:

a) obtain written permission from the government of the country of origin of the applicant through the embassy or representative of the applicant country in Indonesia;

b) obtain written permission from the Minister; and

c) Through childcare institutions.

In addition, prospective adoptive parents must also meet the following requirements:

a) has resided in Indonesia legally for 2 (two) years;

b) obtain written approval from the government of the applicant country; and

c) Make a written statement reporting the child's development to the Ministry of Foreign Affairs of the Republic of Indonesia through the local Republic of Indonesia Representative.

If OCI-related provisions are implemented, the provisions related to the above must be excluded for OCI card holder.

\subsection{The right to get a job without a work permit}

The rules regarding foreign workers contained in Law Number 13 of 2003 on Labor are contained in Article 42; 
1) Every employer that employs foreign workers must have written permission from the Minister or a designated official.

2) Employers of individuals are prohibited from employing foreign workers.

3) The obligation to have a permit as referred to in paragraph (1), does not apply to representatives of foreign countries that use foreign workers as diplomatic and consular employees.

4) Foreign workers can be employed in Indonesia only in employment relations for certain positions and at certain times.

5) Provisions regarding certain positions and certain times as referred to in paragraph (4) shall be stipulated by a Ministerial Decree.

6) Foreign workers as referred to in paragraph (4) whose work period has expired and cannot be extended can be replaced by other foreign workers.

If the OCI card system is implemented in the Indonesian constitutional system, then the treatment of Indonesian citizens and foreigners who are OCI holders will be equal, so the provisions in the Manpower Act must be amended.

In addition to the above, there are many rules in the law that must make adjustments if OCI is implemented in Indonesia. Because OCI system applies a residual theory where things that are not allowed means that it is permissible. Even though there are many positive laws in Indonesia that are different from the laws in other countries. As an example related to the Marriage Law, the same sex marriage is prohibited in Indonesia, while in a number of other countries such as the Netherlands it is permissible. How does Indonesian law regulate related to these conditions? The application of OCI must notice to very detailed matters so that there are no multiple interpretations if this idea is truly implemented in the Indonesian constitutional system.

\section{Conclusion}

The big idea of the Indonesian diaspora so that the Indonesian Government imitates the OCI concept practiced in India still looks very premature. This is because the OCI system is still abstract mentioned as a form of compromise between the Government of India and the Diaspora regarding the demand for dual citizenship. Issues are not only related to security aspects, but the implementation of OCI will change a number of laws which previously distinguish between constitutional rights of Indonesian citizens and aliens. The implementation of the OCI also implies causing legal confusion if in the end there is a different law between Indonesia and other countries.

As a concept that has been practiced in India, the OCI has indeed succeeded in growing the Indian economy, but one thing that needs to be considered besides security is the OCI concept will potentially make Indonesia controlled by foreigners who hold OCI, because in terms of economic stability, the Indonesian diaspora is certainly have better financial strength than Indonesian citizens. Given the right to buy property, then it 
could be that Indonesian land and property in the future will be controlled by foreigners.

\section{References}

\section{Books}

Asshidiqie, Jimly, (2007), Pokok-Pokok Hukum Tata Negara Indonesia, Jakarta: PT Bhuana Ilmu Populer.

Naujoks, Daniel, (2013), Migration, Citizenship, and Development. Diasporic Membership Policies and Overseas Indians in the United States, New Delhi: Oxford University Press.

\section{Journal}

Binod Khadria, (2009), Adversary Analysis and the Quest for Global Development Optimizing the Dynamic Conflict of Interest in Transnational Migration, Social Analysis, Volume 53, Issue 3.

Kurniawan, M. Beni (2018), Penggunaan Diskresi Dalam Pemberian Status Kewarganegaraan Indonesia Terhadap Archandra Thahar Ditinjau Dari Asas Pemerintahan Yang Baik, Jurnal Penelitian Hukum De Jure, Vol. 18 No. 2.

Rokilah, (2017), Implikasi Kewarganegaraan Ganda Bagi Warga Negara Indonesia, Jurnal Ajudikasi .Vol.1 No.2.

Liu, Lisong, (2012), Return Migration and Selective Citizenship A Study of Returning Chinese Professional Migrants from the United States, Journal of Asian American Studies; Baltimore Vol. 15, Iss. 1.

K. Soni, Sharad, (2000), The United Nations Commission On Human Rights (55th Session) : A Report, Himalayan and Central Asian Studies, Vol. 4 No. 2.

Sejersen, Tanja Brøndsted, (2008), I Vow to Thee My Countries - The Expansion of Dual Citizenship in the 21st Century, The International Migration Review, No. 42.

Aggrian, Jum, (2012), Penerapan Asas Nasionalitas dalam Perundang-undangan Agraria Indonesia, Studi Kasus PP No.40 Tahun 1996, Jurnal Dinamika Hukum Vol. 12 No.1.

\section{Internet}

https:/ / tirto.id/saat-diaspora-indonesia-menuntut-kewarganegaraanganda-crPo diakses pada tanggal 12 April 2019

http:/ / dlgimmigration.com/ united-states-citizenship/countries-that-allowdual-citizenship/ diakses pada tanggal 12 April 2019

https://vittana.org/16-big-pros-and-cons-of-dual-citizenship diakses pada tanggal 7 April 2019

https:/ / web.archive.org/web/20170422124533/https:/ /in.usembassy.gov/ u-s-citizen-services/citizenship-services/dual-nationality/diakses pada tanggal 10 April 2019 
https:/ / ociservices.gov.in/ diakses pada tanggal 10 April 2019

https://www.ndtv.com/indians-abroad/supreme-court-dismisses-plea-forvoting-rights-of-overseas-citizens-756654 diakses pada tanggal 10 April 2019

https://money.kompas.com/read/2015/09/16/134501326/OJK.Terbitkan.A turan.Penyederhanaan.Buka.Rekening.Bank.untuk.WNA diakses pada tanggal 12 April 2019 